\title{
A New Treatment Modality Using Topical Sulfasalazine for Oral Lichen Planus
}

\author{
Sung-Hee Jeong, D.M.D.,M.S.D.,Ph.D., Su-Hyeon Park, D.D.S., \\ Soo-Min Ok, D.D.S.,M.S.D.,Ph.D., Jun-Young Heo, D.D.S.,M.S.D., \\ Myung-Yun Ko, D.D.S.,M.S.D.,Ph.D., Yong-Woo Ahn, D.D.S.,M.S.D.,Ph.D. \\ Department of Oral Medicine, School of Dentistry, Pusan National University
}

Background Oral lichen planus (OLP) is a chronic inflammatory disease characterized by cell-mediated immune responses, but the exact cause is unknown. Sulfasalazine has shown efficacy in the treatment of cutaneous lichen planus.

Objective Our purpose was to assess the usefulness of sulfasalazine in treatment of OLP resistant to corticosteroid therapy. This study provides a new option for controlling OLP symptoms.

Methods Two patients with the symptomatic reticular form of OLP were treated with $30 \mathrm{mg} / 5 \mathrm{ml}$ of topical sulfasalazine for 8 to 15 weeks and were evaluated for symptom severity using a numerical analog scale during each week of treatment. The lesion size was measured using a $2 \mathrm{~mm}^{2}$ grid.

Results After 2 weeks of application, both patients reported improvements in their symptoms and lesions. Most of the lesions disappeared after 8 weeks of treatment without any side effects.

Conclusion Topical sulfasalazine can be a successful treatment option for patients with oral lichen planus resistant to steroid therapy.

Key words : Oral lichen planus, Resistant to corticosteroid, Sulfasalazine, Topical application

\section{INTRODUCTION}

Oral lichen planus (OLP) is known as a $\mathrm{T}$ lymphocyte-mediated disease. Many clinical forms

\section{Corresponding author: Yong-Woo Ahn}

Department of Oral Medicine, School of Dentistry, Pusan National University, Beomeo-ri, Mulgeum-eup,

Yangsan-si, Gyeongsangnam-do, 626-770, Republic of Korea

Telephone: 82-55-360-5241

Fax: 82-55-360-5029

E-mail address: ahnyongw@pusan.ac.kr

Received: 2012-08-17

Accepted: 2012-09-13

* This study was supported by Clinical Research Grant Pusan National University Hospital (2010) of OLP have been reported, including reticular, erosive, ulcerative, plaque and a mixed type. Patients with erosive and ulcerative lesions typically report soreness, difficulties eating, drinking, tooth brushing and speaking ${ }^{1}$. Several immunosuppressants, including corticosteroids, cyclosporine ${ }^{2}$, and tacrolimus $^{3}$, are widely used to reduce pain and inflammation in OLP. Topical applications are primarily used because of the ease of application. In the absence of a response to applied topical medications, intralesional injection or systemic administration should be considered. However, several side effects of these drugs have been reported and limit their use $\mathrm{e}^{4}$.

Sulfasalazine is extensively used in inflammatory bowel disease and also has effects on immune- 
related inflammatory diseases, such as Crohn's disease, rheumatoid arthritis, and Behcet's disease. Sulfasalazine also has efficacy for treating dermatological diseases, such as psoriasis ${ }^{5}$, alopecia areata $^{6}$, and lichen planus $(\mathrm{LP})^{7}$. Therefore, the aim of this report is to confirm the effects of sulfasalazine topical application in patients with symptomatic OLP.

\section{PATIENTS AND METHODS}

\section{Case description}

Case 1: A 56-year-old woman presented with the reticular form of OLP on both buccal mucosa and the vestibules, which had persisted for 2 years. She reported soreness and a burning sensation to dentifrice and spicy food. She complained of increasing discomfort when yawning, especially in the morning. Her medical history contained hypertension. The same lesions had been treated at an ENT clinic for 1 year, but the regimen was not effective. The symptoms of discomfort were intermittent.
An examination of the oral cavity revealed white lines (Wickham's striae) on both buccal mucosa and every vestibule; ulcerative lesions were located on the left posterior vestibule (Fig. 1). There were no lesions on the floor of the mouth, palate or tongue. Further examination revealed no cutaneous lesions, and routine hematologic investigations yielded negative results. She was prescribed corticosteroids, including topical and systemic applications, for 1 year but still reported the same complications.

Case 2: A 39-year-old man presented with a 3-month history of oral lichen planus with reticular lesions on both buccal mucosa. Gold crowns had been placed on his right maxillary 1st and 2nd molars 8 years prior to his presentation. He was a smoker but had no medical history of any other diseases. The lesions on both buccal mucosa are irritated by toothpaste, salty food and spicy food, and the patient reports increased discomfort when opening his mouth.

White reticular striations (Wickham's striae) were found bilaterally on the buccal mucosa, but

Table 1. Size of the lesions and self-reported pain (NAS)

\begin{tabular}{ccc|ccc}
\hline \multicolumn{2}{c|}{ case 1 } & \multicolumn{3}{c}{ case 2 } \\
\hline $\begin{array}{c}\text { Time } \\
\text { (week) }\end{array}$ & NAS & $\begin{array}{c}\text { size of lesions } \\
\left(\mathrm{mm}^{2}\right)\end{array}$ & $\begin{array}{c}\text { Time } \\
(\text { week })\end{array}$ & NAS & $\begin{array}{c}\text { size of lesions } \\
\left(\mathrm{mm}^{2}\right)\end{array}$ \\
\hline \hline before & 5 & 769 & before & 6 & 180 \\
1 & 5 & 504 & 1 & 5 & 156 \\
2 & 4 & 496 & 2 & 4.5 & 98 \\
3 & 3 & 544 & 3 & 4.5 & 38 \\
4 & 3 & 568 & 4 & 4.5 & 36 \\
5 & 2 & 492 & 6 & 4 & 40 \\
6 & 2 & 348 & 8 & 3.5 & 46 \\
7 & 2 & 204 & 10 & 3 & 26 \\
8 & 2 & 168 & 15 & 3 & 32 \\
$10 *$ & 2 & 156 & $20 *$ & 3 & \\
\hline
\end{tabular}

$*$; follow-up check period 

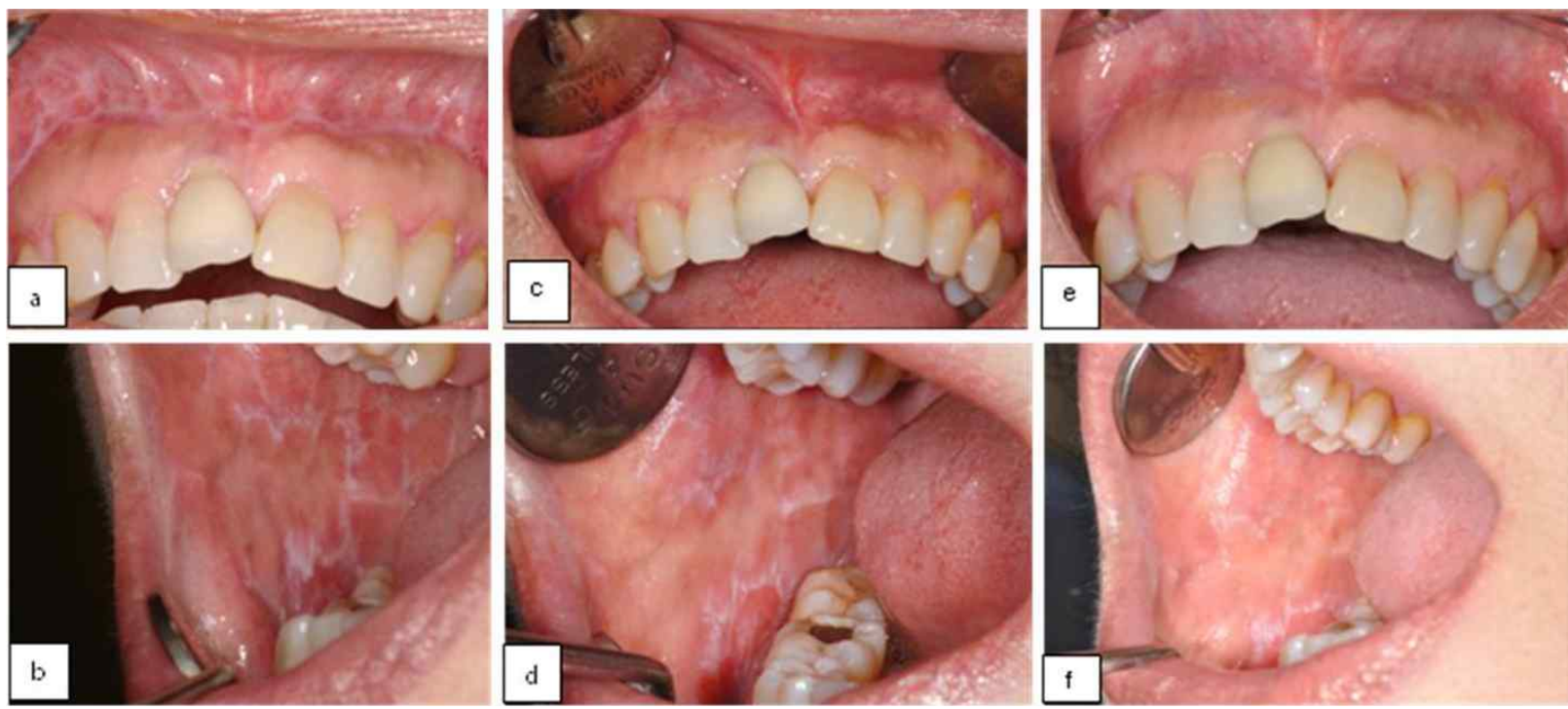

Fig. 1. a-f. Clinical photos of case 1. Upper vestibule(a) and right buccal mucosa(b) at initial stage, 8 weeks of treatment $(c, d), 4$ weeks after treatment $(e, f)$

erosive or ulcerative oral lesions and skin lesions were not identified (Fig. 2). A general examination did not detect any underlying systemic disorders. He was treated with topical and systemic corticosteroids over a 5-month period, but clinical improvement was not observed.

\section{Topical sulfasalazine application procedure and results}

The patients were taught to maintain proper plaque control with commercially available dentifrice not containing sodium lauryl sulfate (SLS-free dentifrice). Both patients agreed to this trial and
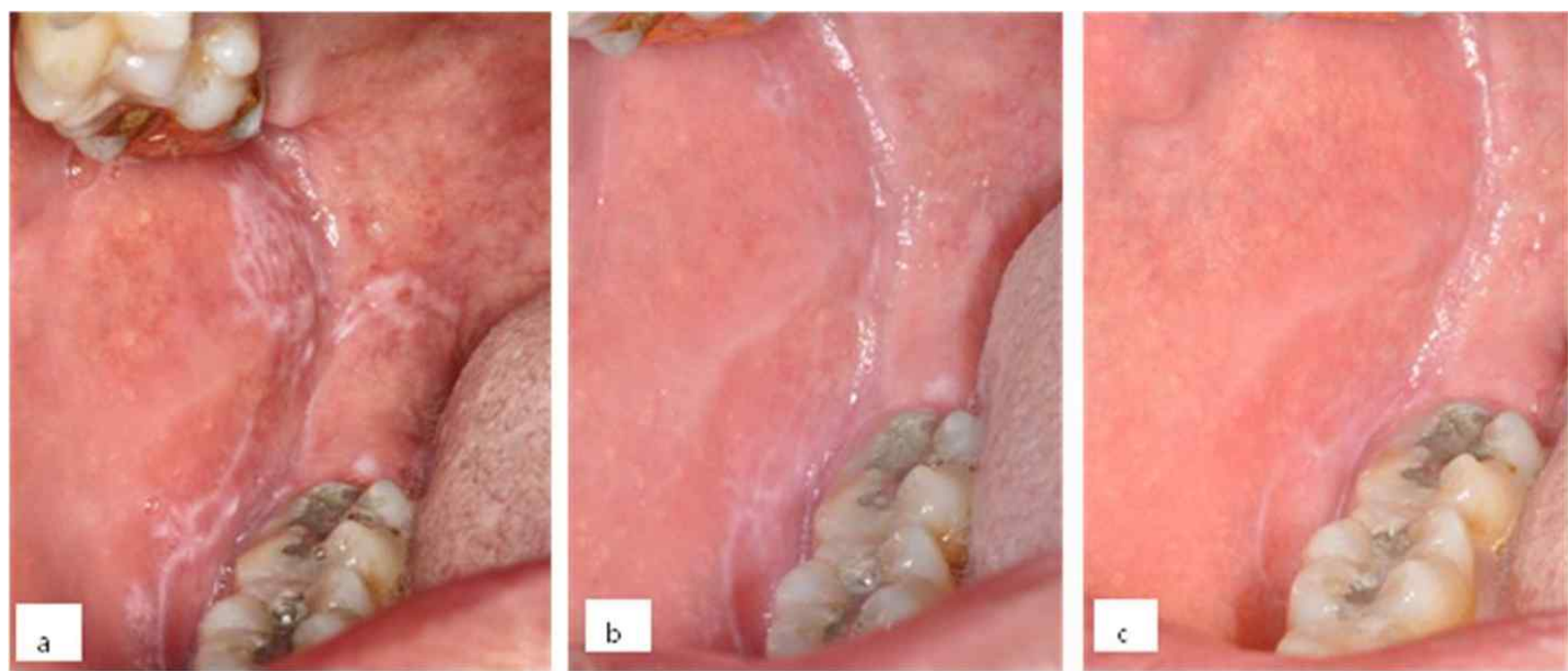

Fig. 2. a-c. Clinical photos of case 2. Right buccal mucosa at initial stage (a), 15 weeks of treatment (b), 5 weeks after treatment (c) 
were provided with a full description of sulfasalazine and its proper use. The solution contains sulfasalazine powder (supplied by Hanlim Pharm. Co.) at $30 \mathrm{mg}$ in $5 \mathrm{ml}$ distilled water and is applied three times a day for $3-5$ minutes. The patients were required not to eat or drink for 30 minutes after treatment and were prohibited from using any other medication except to treat hypertension.

To evaluate the symptom severity, the patients were asked to use a numerical analog scale (NAS, range $0-10$ ), and the lesions were recorded using a transparent grid divided into $2 \mathrm{~mm}$ squares. The grid was placed over the lesion, and the lesion was traced. This evaluation was recorded every week before and after using topical sulfasalazine.

In case 1 , topical sulfasalazine was applied for 8 weeks, and the patient was followed up at 4 weeks after completing the treatment course. She reported feeling better 2 weeks after using topical sulfasalazine, and the reticular form was reduced 8 weeks after (Fig. 1).

In case 2, the treatment was applied for 15 weeks, and the patient was followed up 3 months after the end of the treatment course. After 2 weeks of application, the patient did not complain of any discomfort. After 8 weeks of treatment, he reported that most of the lesion on the right buccal mucosa had disappeared, except for the lesion on the left lower vestibule. He reported that the burning sensations to food and toothpaste had disappeared. Lesion and symptom remission was maintained following the end of the treatment course (Fig. 2).

\section{DISCUSSION}

Sulfasalazine is used to treat ulcerative colitis and Crohn's disease and is a second-line drug for rheumatoid arthritis. In previous studies, sulfasalazine was regarded as a therapeutic option in the treatment of LP without major adverse effects $^{7,8}$. In those studies, the researchers found that oral administration of sulfasalazine was not effective on mucosal LP.

Following oral administration, intestinal bacteria process sulfasalazine into two products, 5-aminosalicylic acid (5-ASA) and sulfapyridine. Sulfapyridine is known to have antimicrobial effects, whereas 5-ASA has anti-inflammatory actions ${ }^{9}$. The oral environment is very similar to the intestine, in that they contain many of the same bacterial species, they are lubricated by mucus, and they have a rich blood supply. Therefore, we hypothesized that the topical application of the drug to the oral mucosa would be more effective than systemic delivery.

The current study confirms that topical sulfasalazine has an effect on OLP. Both patients with OLP showed a very good response to topical sulfasalazine, and side effects were not observed. The diminished white lines and symptoms were maintained after treatment with topical sulfasalazine. Both patients reported a reduced burning sensation after 2 weeks and diminished white lines after 8 weeks.

Traditionally, corticosteroids are regarded as symptom-relieving agents for OLP, but the patients selected for this study had not responded to corticosteroid therapy. Reticular OLP is considered asymptomatic and does not usually require treatment. In this study, the patients had symptomatic reticular OLP, characterized by lesions resistant to steroid therapy. The exact mechanism of topical sulfasalazine action on OLP is not completely understood. However, the results of this investigation show that patients treated with topical sulfasalazine report a positive response without any side effects.

Therefore, topical sulfasalazine can be considered as a replacement therapy for OLP resistant to corticosteroids.

\section{REFERENCES}

1. Eisen D. The clinical features, malignant potential, and systemic associations of oral lichen planus: A study of 723 patients. J Am Acad Dermatol 2002; 46: 207-214.

2. Demitsu T, Sato $\mathrm{T}$, Inoue $\mathrm{T}$, et al. Corticosteroidresistant erosive oral lichen planus successfully treated with topical cyclosporine therapy. Int J Dermatol 2000; 39: $79-80$. 
3. Edwards PC, Kelsch R. Oral lichen planus: Clinical presentation and management. $J$ can Dent Assoc 2002; 68: 494-499

4. Farhi D, Dupin N. Pathophysiology, etiologic factors, and clinical management of oral lichen planus, part I: Facts and controversies. Clin Dermatol 2010; 28: 100-108

5. el-Mofty M, el-Darouti M, Rasheed H, et al. Sulfasalazine and pentoxifylline in psoriasis: A possible safe alternative. J Dermatolog Treat 2011; 22: 31-37.

6. Rashidi T, Mahd AA. Treatment of persistent alopecia areata with sulfasalazine. Int J Dermatol 2008; 47: 850-852.
7. Bauza A, Espana A, Gil P, et al. Successful treatment of lichen planus with sulfasalazine in 20 patients. Int $J$ Dermatol 2005; 44: 158-162.

8. Omidian M, Ayoobi A, Mapar M, et al. Efficacy of sulfasalazine in the treatment of generalized lichen planus: Randomized double-blinded clinical trial on 52 patients. J Eur Acad Dermatol Venereol 2010; .

9. McGirt LY, Vasagar K, Gober LM, et al. Successful treatment of recalcitrant chronic idiopathic urticaria with sulfasalazine. Arch Dermatol 2006; 142: 13371342.

\title{
국문초록
}

\section{구강편평태선에 대한 sulfasalzine의 국소적용}

\author{
부산대학교 치의학전문대학원 구강내과학교실
}

정성희 · 박수현 · 옥수민 · 허준영 · 고명연 · 안용우

구강편평태선은 면역매개성 반응으로 유발되는 만성염증질환으로 정의할 수 있으며 그 정확한 원인은 아직 밝혀지지 않은 상태이다. 일반적으로 스테로이드를 이용한 국소적 또는 전신적 치료를 시행하고 있으나 스테로이드 치료에 반응이 없는 환 자의 경우에는 치료가 힘들다.

Sulfasalzine은 염증성 장질환을 치료하기 위한 약물로 선택되고 있고 류마티스성 관절염에서도 치료제로 사용하고 있다. 염증성 장질환과 구강편평태선에서 발병기전을 살펴보면 공통적인 부분이 많이 발견된다. 전신적으로 투여시 나타나는 부작 용을 최소화하고 접근의 편이성을 위하여 Sulfasalzine을 구강편평태선에 국소 도포의 형태로 시도하였으며, 본 연구에서는 성공적으로 치료한 2 치험례를 소개하였다. 첫번째 증례에서는 8 주간의 도포 $(30 \mathrm{mg} / 5 \mathrm{ml}$, 하루3번) 후 증상이 완화되었으며, 두번째 증례에서는 15 주간의 도포 후 증상이 완화되었다. 두 증례 모두 스테로이드에 치료반응이 없었던 환자였으며 sulfasalazine 도포 후 현재까지 증상이 완화된 상태로 지내고 있다.

따라서 Sulfasalazine은 구강편평태선환자에서 치료약물로 선택될 수 있다는 결론을 얻었다.

주제어: 구강편평태선, 국소적용, 설파살라진 